DOI https://doi.org/10.18551/rjoas.2020-10.16

\title{
PRODUCTION MANAGEMENT AND VALUE CHAIN OF CORN COMMODITY
}

\author{
Dwijatenaya Ida Bagus Made Agung ${ }^{\star}$, Raden Ince, Thamrin, Damayanti Arista \\ Faculty of Agriculture, University of Kutai Kartanegara, East Kalimantan, Indonesia \\ *E-mail: dwijatenaya@yahoo.co.id
}

\begin{abstract}
This study aims to analyze the management of corn production and farming, analyze the corn value chain, analyze the difference in marketing margins between the corn commodity value chain actors, and analyze the marketing efficiency among value chain actors. The study was conducted in Kutai Kartanegara Regency, East Kalimantan Province, Indonesia by taking six sub-districts as samples, namely Samboja, Sebulu, Tenggarong, Tenggarong Seberang, Marangkayu, and Muara Badak Sub-Districts. The number of samples for farmers is 240 respondents using the random sampling method and the channel informant is determined by the snowball method. The results showed that the corn farm production management function was good, only the production control function showed that corn production was still low. The results of the analysis for corn farming from 240 respondents with an area of 352 ha totalling $653,290 \mathrm{~kg}$ with an average of 1,855.94 $\mathrm{kg}$ per hectare. The price of corn at the time of the study was an average of IDR 4,267 per kg. The total farm income per planting season is IDR 4,938,016,750. The total cost is IDR $1,747,582,947$ per planting season. Income of IDR 3,190,433,803 per planting season. R/C ratio obtained 2.82 means that corn farming is feasible to be cultivated. The main actors in the corn value chain are farmers, village / sub-district collectors, district collectors, retailers and consumers. Corn supply chain channels are channel 0 , channel $1 \mathrm{~A}, 1 \mathrm{~B}$, channel 2 , and channel 3 . The margin received by village (sub-district) collectors on channel $1 \mathrm{~A}$ is IDR 3,281 , channel 2 is IDR 2,200 , and channel 3 is IDR 1,875. The margin received by district collectors on channel 3 is IDR 1,250. The margin received by retailers in the IB channel is IDR 3,750, - on channel 2, it is IDR 1,800, and on channel 3 , it is IDR 1,750, -. The efficiency value of all marketing institutions involved in corn marketing activities in Kutai Kartanegara Regency is $<1$ which means efficient.
\end{abstract}

\section{KEY WORDS}

Production management, corn farming, value chains, supply chains, marketing margins, marketing efficiency.

Corn is a strategic commodity that is needed for many industries because it is a source of carbohydrates. Besides functioning as an ingredient of animal feeds, corn also has an important role in the national economy and has been a contributor to Gross Domestic Product (GDP). Corn (Zea mays) is a strategic and economically valuable cereal and has the opportunity to be developed because of its position as the main source of carbohydrates and protein after rice. Almost all parts of corn plants can be used for various purposes. Stems and leaves of young plants can be used for animal feed, old ones (after harvesting) can be used for green manure or compost.

The number of maize production every year has a skyward trend accompanied by an increasing number of productivity. Raised rate of domestic corn production (in Indonesia) is certainly influenced by the high demand for animal feed. this is supported by the opinion of Haryono (2012) that the proportion of the use of corn for feed to total corn needs reached 83 per cent and Tangenjaya et. al. (2002) that the composition of feed derived from corn is for broilers 54 per cent and laying hens 47.14 per cent. The Indonesian government makes corn as a strategic commodity to be developed. Thus the regional government, both provincial and district/city governments develop this commodity. Including the regional government of East Kalimantan Province (East Kalimantan) and the Regency of Kutai Kartanegara (Kukar) which is famous for its corn revolution program. The East Kalimantan Food Crops and 
Horticulture Office is currently boosting the production of corn in regencies and cities throughout East Kalimantan because the demand for corn has never declined. In 2018 corn production in East Kalimantan was recognized to have a surplus of 36,917 tons were in 2016 corn production amounted to 22,132 tons and in 2017 it rose to 56,597 tons. The productivity of this corn plant is an average of seven tons per hectare of dried pipil. (Poskaltim.com, 2019).

In general, corn farming is carried out to run effectively and efficiently through a pattern of good and professional management. Production management has the same importance as marketing management, financial management, accounting management and personnel management. Management has functions that include the functions of planning, organization, implementation, and supervision (Supari, Dh, 2001).

Evaluation of the performance of production management and the value chain of corn commodities is very important to do. In the value chain is to assess all actors involved starting from the provision of production facilities, production processes, distributors including supply chains, and consumers. According to Michael Porter as quoted by Kotler and Keller (2009) the value chain is a tool to identify ways to create more customers.

The value chain identifies nine strategically relevant activities. Five primary activities and four supporting activities that create value and costs in a specific business. The primary activities are (1) inbound logistics, (2) operation activities, (3) outbound logistics, (4) marketing and sales, ( 5) services. While supporting activities include; 1) procurement, 2) technology development, 3) human resource management, and 4) company infrastructure.

The flow of products from producers to consumers raises the value chain. The activities in each activity can be separated, but are very dependent on each other as illustrated in Figure 1.

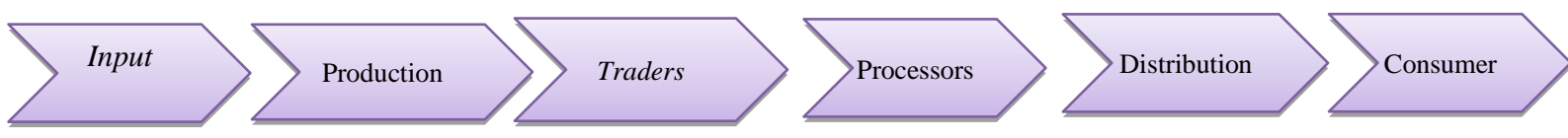

Figure 1 - Value chain systems from Input to Consumer (Source: Kaplinsky in Tanjung, et al., 2013)

Value chain analysis can be used as a strategic analysis tool used to better understand competitive advantage, where companies can increase value-added and reduce costs so they can make businesses more competitive (Porter in Irianto and Widiyanti, 2013). Reji (2013) explains that value chain development emphasizes strengthening market relations. The value chain is explained by Kaplinsky and Morris in Nassirou Ba (2016), "a value chain describes the full range of activities required to bring a product or service through the different phases of production, including physical transformation, the input of various producer services, and response to consumer demand ". It was further said that there were seven stages in value chain analysis, namely: Identification of actors as the starting point for value chain analysis (ie the point of entry for value chain analysis), namely determining the point at which the study began; Value Chain Mapping (actors and product flow, the flow of income, the flow of information), ie go backwards or go forward to determine the income (gain) of each actor obtained through the input-output relationship; Determination of product segments and key factors for the success of the destination market (product segment and critical success factors in the final markets) which includes identifying which parties can be involved to improve the value chain. In this case, it could be NGOs, universities and government institutions that are concerned and are obliged to empower these business actors; Analysis of producer methods for accessing markets (How producers access final markets), in principle, to identify the key success factors; Conduct benchmarking with competitors or similar businesses (Benchmarking production efficiency); Coordinating the value chain with related networks (governance of value chain), and the seventh improvement of the value chain (upgrading the value chain). Research on the value chain has been carried out, among others, by Khoi (2013), Sagagi and Palina (2013), Lizano and Vega (2016), Magar (2016), Tobin (2016), Nassirou Ba (2017), Warsanga and Evans (2018), and Carlos (2018). 
In marketing agricultural commodities, the two groups of activities forming the value chain are also carried out although with different complexity from activities in the industrial field. Therefore, marketing efficiency efforts need to be made to save costs and increase competitiveness and in turn increase profits. Value Chain (VA) is several activities that create value (value-creation) in various forms starting from the initial source (raw material) to the formation of final goods and delivery of goods to the hands of end consumers (Dekker in Nur and Salim, 2014). At the level of production (farming) in general, planting of corn is carried out simultaneously, so that harvest time is also carried out simultaneously. As a result of the simultaneous harvest, abundant products at that time directly implicated in falling prices. Conversely, a lack of supply during the lean season results in animal feed factories (as the main consumers of domestic corn) having to bring in imported corn. Furthermore, at the distribution level, namely the length of the marketing chain in the marketing process of corn from farmers, the impact is the low margins. Marketing margins are the difference in prices paid by consumers and prices received by farmers. While there is an assumption that the greater the marketing margin the more inefficient a marketing process. But this assumption is not entirely true because this marketing margin essentially consists of the costs to carry out marketing functions and the advantages of marketing institutions. Then the strategy to improve marketing efficiency and profitability of marketing institutions can be done by expanding the market and reducing marketing margins.

Farmers in marketing their products do not have freedom. This is caused by the dependence on middlemen as a result of the lack of capital owned when the planting season arrives and the lack of institutional role at the farm level. Farmers must be willing to release their production at harvest to middlemen because they are bound by production facilities debt which results in the majority of the income received by farmers after harvest is allocated to pay the loan principal along with a very high-interest rate. The purpose of this study is to analyze the management of corn production and farming, analyze the corn value chain, analyze the difference in marketing margins between corn commodity value chain actors, and analyze the efficiency of marketing between value chain actors.

\section{METHODS OF RESEARCH}

This research uses descriptive quantitative research design. To analyze the management of corn agribusiness production is done descriptively. Furthermore, to analyze the corn value chain, six sub-districts were selected that had the largest planting area out of the 18 sub-districts in Kutai Kartanegara Regency, East Kalimantan. These sub-districts are Muara Badak, Sebulu, Samboja, Tenggarong, Tenggarong Seberang, and Marangkayu. The type of data used is primary and secondary data. Primary data sourced from direct research collected through questionnaires and interviews with farmers in six sample sub-districts, collectors, small traders and large traders. Primary data reviewed include; 1) production and production costs of corn farming, 2) actors involved in the corn value chain and its role, 3) distribution and marketing margins of corn commodity. While secondary data is obtained from data that has been available at the relevant institution or agency and through other documentation.

Determination of the sample for corn farmers using multistage sampling using two stages, where the first stage is determining the location/area of research using a purposive sampling method, ie the sample is taken with the intent and purpose of which sub-district has the largest land area, in this study selected six sub-districts, namely; Muara Badak, Sebulu, Samboja, Tenggarong, Tenggarong Seberang, and Marangkayu Sub-Districts. This selection is based on the consideration that the district is the most widely planted in corn and can be directed as a centre of corn. The next step is to determine the number of samples using the proportional stratified sampling method. Thus the number of samples used was 240 farmers, with details for each district are; (1) Samboja Sub-District as many as 30 farmers, (2) Tenggarong Sub-District as many as 30 farmers, (3) Sebulu Sub-District as many as 40 farmers, (4) Tenggarong Seberang Sub-District as many as 30 farmers, (5) Muara Badak Sub-District as many as 70 farmers, and Marangkayu Sub-District as many as 40 farmers. 
The sampling technique for channel informants on each actor using the Snowball Sampling method. Based on this method the flow of corn commodity from farmers to consumers can be known so that the marketing chain of corn that is formed can be identified in real terms (Irianto and Mardikanto in Widiastuti and Harisudin, 2013). The channel informants consisted of 16 collectors, 23 retailers, 23 consumers and 5 industry customers.

The method used in analyzing the cost of corn farming is to calculate all costs incurred in corn farming for one growing season. Production produced if multiplied by the price, the amount of revenue obtained. Furthermore, income is calculated using the following formula (Supari. Dh, 2001).

$$
\pi=T R-T C
$$

Where: $\Pi=$ Revenue; TR = Total Revenue; TC = Total Cost

Value chain analysis uses several steps considered as written by Irianto and Widiyanti (2013), including; entry points, value chain mapping (actors and product flow, the flow of income, flow of information), analysis of governance structures, and critical success factors. Trading system margins obtained by supply chain actors are calculated using the following formula.

$$
\mathrm{Mi}=\mathrm{Hji}-\mathrm{Hbi}
$$

Where: $\mathrm{Mi}=$ Trading system margin at an i-level market (IDR per $\mathrm{kg}) ; \mathrm{Hji}=$ The selling price of corn on the i-level market (IDR per $\mathrm{kg}$ ); $\mathrm{Hbi}=$ The purchase price of corn on the i-level market (IDR per kg); i = 1,2,3, ... n.

Furthermore, marketing efficiency is calculated using the concept of marketing efficiency where marketing efficiency is a comparison between the total cost and the total value of corn marketed so that it can be formulated (Soekartawi, 1989), as follows:

$$
\text { Eps }=\mathrm{Bp} / \text { Mobile }
$$

Where: EPS - Marketing efficiency (\%); Bp - Marketing costs; HP - Sales price.

\section{RESULTS AND DISCUSSION}

Management and organizational aspects are important in a business, including in the farming of shelled corn. The management functions contained in this corn farmer are the planning function, organizational function, implementation function, and evaluation function. The management functions of shelled corn farming in Kutai Kartanegara Regency are explained as follows:

Planning. This farming starts with the planning of what should be done to achieve good results. Corn farmers in Kutai Kartanegara Regency are incorporated in a group of farmer groups. So that in all the activities planned by members led by the head of the farmer group. Planned activities start from planning the use of inputs, production processes to marketing. In the activities of the farmer's group production process, they plan the time to cultivate the land, harvesting seeds, planting, maintaining and marketing planning. Marketing planning involves the selection of marketing channels so that the results of shelled corn reaches consumers.

Organizing. The form of organization of shelled corn farming is in the form of farmer groups. Then several farmer groups joined in a joint farmer group (GAPOKTAN). Because corn farming in Kutai Kartanegara Regency is a district government program known as the corn revolution program, it is very easy for farmers to be directed into farmer groups. Organizing is useful in achieving business efficiency. According to the results of interviews in the field, farmers joined the farmer groups because it was easy to get information, get guidance from the government, and others. The other benefits obtained by farmers when joining a farmer group are being able to exchange information, be able to consult and share 
and gain knowledge of corn cultivation and other techniques that can increase production yields.

Actuating. Various aspects must be considered in corn farming. In this research, the aspects of farming and marketing aspects will be examined. Actors in the corn value chain are also the focus of this study. Farmers as maize producers are the main actors in the management of corn production and value chains The determining factor of the corn value chain is the availability of quality maize by market demand and a stable amount of supply. Corn farming began to be intensively developed by farmers in this area since the launch of the Kutai Kartanegara District Government Program on the Corn Revolution. Efforts to increase corn production have been carried out. Farmers in Kutai Kartanegara Regency have used superior seeds to increase their corn farming production. Varieties used by farmers vary, including Bisi 18, Bisi 228, Nasa 29, and NK 212.

Controlling. The controlling process is carried out to find out how much the targets have been achieved and what has not been achieved in the cultivation of shelled corn in Kutai Kartanegara Regency, East Kalimantan Province. The supervision includes supervision of the number of products produced and quality control of the production. Based on the results of the study shows that the production of shelled corn in this area is still considered low. Whereas supervision for the dryness of shelled corn is quite good at an average of 14 per cent.

Analysis of farming. The total land area of 240 respondents is 352 ha with an average land area of 1.47 ha per respondent. The total production yield was $653,290 \mathrm{~kg}$ with an average of $2722.04 \mathrm{~kg}$ per respondent and 1,855.94 kg per ha. Corn production is still low, partly due to drought due to the dry season. Revenue is the result of multiplication between production and selling prices. The selling price at the time of the research activity was an average of IDR 4267 per $\mathrm{kg}$. So, the total farm income per planting season was IDR $4,938,016,750$ with an average of IDR $2,748,685,000$ per ha and an average of IDR $11,452,854$ per farmer. It is assumed for one planting season for three months so that the average income is IDR 6,858,357 per month per farmer. Income is the difference between revenue and total costs. Based on the calculation results the total cost is IDR 1,747,582,947 per planting season so that an income of IDR $3,190,433,803$ per planting season or IDR $4,431,158$ per ha per planting season and IDR 9,103,732 per farmer per planting season or IDR 3,021,244 per farmer per month, as detailed in Table 1.

Table 1 - Corn Farmers' Revenue, Costs and Income in Kutai Kartanegara Regency, East Kalimantan, 2020

\begin{tabular}{ccccc}
\hline Description & Total per planting & $\begin{array}{c}\text { Average } \\
\text { per hectare }\end{array}$ & $\begin{array}{c}\text { Average per farmer } \\
\text { per planting season }\end{array}$ & $\begin{array}{c}\text { Average per farmer } \\
\text { per month }\end{array}$ \\
\hline Production & $653.290 \mathrm{~kg}$ & $2.722 \mathrm{~kg}$ & $1.855,94 \mathrm{~kg}$ & - \\
Price & 4.267 & - & IDR 14.028.457 & - \\
Revenue & IDR 4.938 .016 .750 & IDR 6.858 .357 & IDR 4.964.724 & IDR 4.676.152 \\
Costs & IDR 1.747.582.947 & IDR 2.427.199 & IDR 1.654.908 \\
Profit & IDR 3.190.433.803 & IDR 4.431.158 & IDR 9.063.732 & IDR 3.021.244 \\
\hline
\end{tabular}

Source: Primary data, processed by researchers, 2020.

A business declared feasible or not to be attempted can be seen from the ratio of revenue and costs incurred on the business. According to Suratiyah (2006), a farm is said to be feasible if it fulfils several criteria, one of which is if the ratio between revenue and total cost $(R / C$ ratio $)>1$. Based on the calculation results, the $R / C$ ratio value of 2.82 shows that each Rp. 1 costs incurred will get an income of Rp. 2.82 and income value of Rp. 1.82. This shows that corn farming in Kutai Kartanegara Regency has provided benefits to farmers so that it is feasible to continue to be cultivated.

Value chain analysis (VCA). The corn revolution promoted by the Government of Kutai Kartanegara Regency in East Kalimantan has encouraged farmers to further improve corn farming. Corn farming is almost spread throughout the district. In addition to the corn revolution, which is the flagship program of the Kutai Kartanegara government, this program 
is also supported by the provincial and central government. So that in its development, corn farming has become one of the people's livelihoods in Kutai Kartanegara Regency.

Corn production in Kutai Kartanegara Regency has not been directed for export purposes. Currently, corn commodity is still to fulfil regional needs. The corn value chain in Kutai Kartanegara Regency, East Kalimantan Province involves three main actors, namely farmers, collectors, and traders. Each actor has a different role according to their interests and needs. These actors have a very strong relationship in running this corn value chain. If one encounters a problem, it will directly or indirectly affect other actors. Likewise, each actor has a different function in creating a stable value chain. The value chain of corn commodity in Kutai Kartanegara Regency starts from farmers and then goes through various stages which finally reach consumers or animal feed industry. These stages are village / sub-district collectors traders, district collectors traders, and retail traders. Furthermore, the role of each actor is explained below:

- Farmers. Farmers carry out the entire process of cultivation starting land preparation, land management, planting, maintenance, and post-harvest (such as threshing corn);

- Collectors. A trader is a person who collects farmers' crops in the form of dry corn and then deposits it to retailers or the industry;

- Traders. Traders are receiving crops from farmers or collectors, and sending them to buyers (consumers) or the animal feed industry.

In addition to planting wet corn (sweet corn), corn farmers in Kutai Kartanegara Regency also plant dry shelled corn. For research purposes, only dry shelled corn is analyzed. Dry shelled corn products sold by farmers have a moisture content of between 13$16 \%$. Corn seeds used by farmers are hybrid corn seeds. The main issue from the aspect of corn production in Kutai Kartanegara Regency is low corn productivity. Based on the results of interviews with respondents that the average productivity is still under five tons per hectare. The average productivity of corn in Kutai Kartanegara Regency is 1,856 tons per hectare. Maize production in Kutai Kartanegara District of East Kalimantan is still low when compared to national corn productivity of 5,241 tons per hectare (source: https://databoks.katadata.co.id/).

Based on the results of interviews with respondents and observations in the field that corn productivity is still low is caused by several factors, namely:

- Some farmers have the low technical ability in corn cultivation. Farmers in several sub-districts have transferred jobs from fishermen to corn farming. This technical ability affects the skills of farmers. As the results of the study show that farmers' skills related to technical abilities in managing corn farming tend to be moderate (68.3\%);

- Most farmers in managing corn farming have less and dominant experience in the medium category. The experience of farmers such as the use of fertilizers and the right dosage is not by the methods of corn cultivation that is good and right. The results showed that the experience of farmers in corn farming as many as 48 per cent of respondents answered answers tend to be quite experienced;

- The climate is sometimes less supportive like when there is a prolonged drought;

- Drainage for planting corn has not been managed properly;

- Not all farmers apply knowledge to increase productivity due to cost constraints.

To maintain the sustainability of corn farming, as stated in the corn revolution program of Kutai Kartanegara Regency, the behaviour of farmers in managing their farms must adhere to the principles of sustainable farming. Farmers' behaviour towards sustainable farming is in a good category. The results showed that the answers of the dominant respondents in the good category were 49.2 per cent. Behaviour towards good sustainable farming needs to be fostered consistently, both by the government, the private sector, and universities.

Almost all of the corn products in Kutai Kartanegara Regency are for the domestic market, not yet for export purposes. The corn crop is sold to collectors and retailers, and a small portion is sold to the animal feed industry in South Kalimantan. As the marketing channel (supply chain) of corn commodity shows that market participants only involve 
collectors, retailers, animal feed industry and consumers. This also proves that the corn crop has not been cultivated for export purposes.

Based on the results of interviews with respondent farmers and direct observations in the field, that in addition to the issue of mastery of corn cultivation skills that have not been good, there are also issues about the price of corn at the farmer level is not stable. For the issue of price instability at the farm level, it tends to be caused by the absence of cost of goods purchased (HPP) as happened in rice commodities. For this reason, the price of corn follows the free market mechanism, which is the law of supply and demand. Price instability is also detrimental to traders. To that end, to provide a favourable price guarantee, the district or provincial government can set regional reference prices as well as in palm oil commodities.

The government has established a policy that Indonesia must achieve sustainable selfsufficiency in corn. As stated in the Strategic Plan of the Ministry of Agriculture 2014-2019 (Permentan Number: 19 / Permentan / HK.140 / 4/2015) in connection with climate problems faced by corn farmers in Kutai Kartanegara Regency in particular and Indonesia in general, the formulation of agricultural development policies that related to climate change impacts are:

1. In anticipating climate change, agricultural policies should prioritize the principle of adaptation without ignoring mitigation actions, so that any action to reduce Greenhouse Gas (GHG) emissions in the agricultural sector must also guarantee supporting efforts to increase production and productivity;

2. Climate change adaptation and mitigation actions must provide benefits in improving the welfare of farmers so that the action activities to be selected must be adapted to the people's farming systems and businesses;

3. Climate change adaptation and mitigation activities are site-specific by taking into account the geographical conditions of each region, so the technology to be applied must be appropriate and site-specific technology by adopting as much local wisdom as possible.

While the strategies adopted in climate change adaptation are:

- Adaptation and development of farming systems to climate change;

- The development and application of adaptive technology to climate stress;

- Optimizing the use of land, water and genetic resources;

- Strengthening the role of all stakeholders through local farmer deliberations in the initial planning of simultaneous planting that adopts a planting calendar and anticipation of climate change.

The policy of increasing corn production by the central government was welcomed by the Government of the District of Kutai Kartanegara through the Corn Revolution policy. In addition to the farmer resource factor as faced by several respondents, farmers are still low. Climatic factors such as now, also determine the success of corn farming.

The government shows its seriousness in meeting national food needs (including corn) through food self-sufficiency by issuing food policies as regulated in RI Law No. 18 of 2012 concerning Food. The policy launched by the government especially in increasing food productivity including corn has been responded by several local governments including Kutai Kartanegara Regency with its policy on the Corn Revolution. However, some challenges that are developing at this time still require the existence of policies at the national level to support the creation of a conducive corn business environment. The required policies include:

- National corn trade policy;

- Corn benchmark price policy (COGS).

Map of the corn value chain in Kutai Kartanegara Regency. A comprehensive value chain map that covers the whole thing will never exist. There are many potential dimensions of the value chain that can be included in the initial mapping activity: product flow, actors involved in the value chain, costs and margins at various levels, and others. Therefore, the selection of mapped dimensions is important, and this is done based on available resources, 
the purpose and scope of value chain analysis, and the mandate of the organization. Based on Kaplinsky's theory in Tanjung, et al. (2013) about the value chain, then in this study compiled a map of the corn commodity value chain as shown in Figure 1.

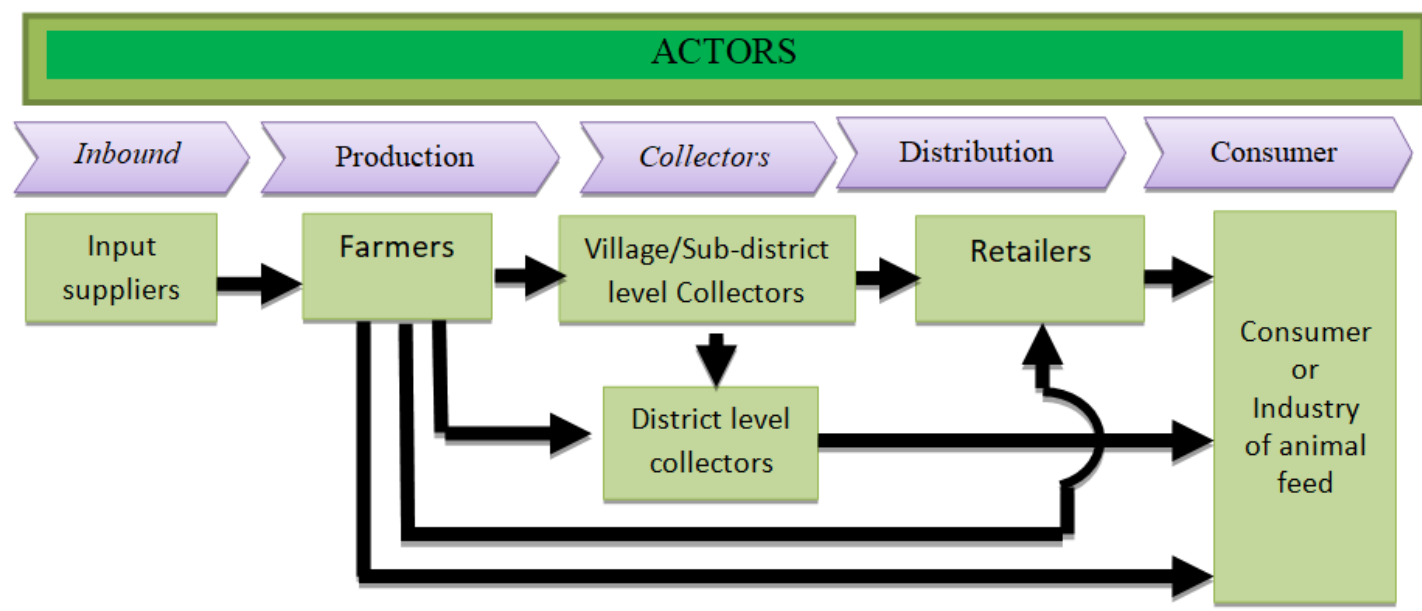

Figure 1 - Map of Corn Commodity Value Chain in Kutai Kartanegara Regency, 2020 (Source: Research Results, processed by Researchers)

The corn value chain map shows several value chain actors in various maize commodities, where the longest flow consists of actors involved consisting of farmers village/district collectors - retailers - consumers, and farmers - village collectors / sub-district collectors district - animal feed industry. The next actors are farmers - district collectors animal feed industry, farmers - retailers - consumers. While the short value chain of maize commodity from production activities carried out directly by corn farmers, consisting of farmers - consumers.

Based on Figure 1 the input process consists of supplying seeds, fertilizers, herbicides, and equipment. Seeds and fertilizers are mostly sourced from government assistance. However, in calculations to meet the analysis objectives, the costs of seeds and fertilizers are assumed to remain as farmers' expenditures. These costs are calculated as purchases of the crop. Crops in the form of dry corn are distributed to consumers and the animal feed industry through collectors and retailers.

Principal Actor Analysis (Actors and Supporting Actors). Actors in the corn commodity value chain in Kutai Kartnegara Regency are grouped into main actors and supporting actors. These actors are explained in full as follows.

A. Main Actor:

1. Farmers. In the value chain of corn commodity in Kutai Kartanegara Regency, farmers have a very important role. The role is that farmers produce corn which eventually forms a value chain. In this study, the number of farmers who were respondents was 240 people. Farmers have diverse farming experience, with different educational backgrounds, as well as different tribes.

Corn farmers in Kutai Kartanagera Regency are spread in 18 districts. Six Sub-Districts have the most extensive planting area among other districts, namely the Sub-Districts of Muara Badak, Sebulu, Marang Kayu, Tenggarong, Samboja, and Tenggarong Seberang. Corn farmers in Kutai Kartanegara Regency consist of various tribes such as; Javanese, Bugis, Banjar, Madura, Balinese, and so on. The origin of this tribe affects the way corn farming. For this reason, it will affect the productivity of corn farming itself.

Based on the results of the study obtained income between farmers in the district one with another varies. The average income of corn farmers in Kutai Kartanegara Regency for one growing season is $\operatorname{Rp~9,063,732.~If~one~planting~season~is~assumed~for~three~months,~}$ the average income of corn farmers in Kutai Kartanegara Regency is Rp. 3,021,244. Even though the productivity of corn farmers in Kutai Kartanegara Regency is lower than the national productivity, this farming is feasible to be worked out as indicated by the R / C Ratio 
of 2.82. Various work backgrounds before becoming a corn farmer, among others, as a fisherman. This resulted in the still low mastery of corn cultivation technology. For this reason, inevitably, corn productivity is still low when compared to national corn productivity.

Based on the income earned by these farmers, it can be said that corn farming cannot be said to be the main occupation of the farmer. Aside from being a corn farmer, his other work is as a labourer, fisherman, and farmer in other farming including oil palm gardening. Corn farmers in Kutai Kartanegara Regency have a good motivation in corn farming especially the government's encouragement through the Corn Revolution Program that is being promoted. The results showed that the motivation of farmers in farming is likely to be good as the results of the research described below:

- The seriousness of farmers in farming corn. Whatever the form of business, then someone in the business is required to be serious in managing the business. Farmer respondents' answers showed that the results of the answers tended to be very good, with the dominant answer being good at 43.8 per cent;

- Farmer's tenacious attitude in corn farming. Farmer's tenacity in farming will lead to success. Respondents' answers to the tenacious attitude of farmers clustered in the very good answers. As many as 51.2 per cent of respondents answered well;

- Consistent attitudes of farmers in corn farming. Farmers' consistency can encourage good and proper corn cultivation. The consistent attitude of not using paddy fields for corn can also maintain the availability of food both corn and rice in Kutai Kartanegara. The results showed that respondents' answers grouped on very consistent answers, which amounted to 81.7 per cent. The most dominant respondent's answer is the consistent answer of 48.8 per cent;

- Responsibilities of farmers in farming corn. Absolute responsibility is needed so that production is as expected. The results showed that respondents' answers clustered on responsible answers by 79.2 per cent;

- Desiring to improve performance. Farmers' resources determine the success of corn agribusiness. Farmers' motivation towards the desire to continuously improve their performance is the main capital in the success of the Corn Revolution Program in Kutai Kartanegara Regency. The results of research on the desire of farmers to improve their performance obtained respondents' answers clustered on good answers by 78.7 per cent. Motivation originating from farmers who are often referred to as intrinsic motivation will have a positive impact on the development of the Corn Revolution Program. As explained that the human resources factor of agribusiness must be improved starting from the farmers themselves. The government is implementing its program, of course, the behaviour of farmers makes the main focus for development.

2. Collectors. Trader collectors or collectors are called sub-district collectors and district collectors. Corn commodity collectors in Kutai Kartanegara Regency generally come from the local (sub-district) area, only a small portion of collectors from other regions. Traders from other regions usually work as managers of corn farmers' associations. Currently, there are collectors in each district with varying amounts. Traders in the Kutai Kartanegara Regency are also farmers and some are retailers. As in Tenggarong and Muara Badak Subdistricts, besides being a collector, he is also a farmer and retailer.

3. Retailers. Retailers are the most important main actors in the corn commodity value chain. Retailers play a role until the commodity is in the hands of consumers. Retailers obtain corn supplies from collectors and directly from farmers. Prices received by retailers from collectors and farmers are mostly the same. Based on the results of the interview, if there are differences in prices between collectors and farmers caused by different water levels. If this happens, the retailer will dry it so that it is by the water content desired by the consumer. The average water content sold to consumers is 14 per cent. Transportation costs from farmers or collectors are charged to retailers.

The pattern of retail business is still very simple. This is caused by small scale businesses. Thus, there are not many workers from outside the family. The main issue faced by most retailers is the absence of a reference price, so prices are set according to market 
mechanisms, namely the higher the demand while the supply of corn decreases, the price increases.

4. Consumers. Consumers are end-users rather than corn products. Consumers of shelled corn in Kutai Kartanegara Regency, in general, are chicken farmers and livestock industries such as the animal feed company PT. Cheil Jedang Feed Kalimantan and CV Chicken Makmur Samarinda. Consumers are directly in the sub-district market.

B. Supporting Actor:

The success of strengthening the corn commodity value chain cannot be separated from the role of supporting actors. The success of this strengthening is determined by the existence of access to information or knowledge, technology and finance and other services. The condition of the actors supporting the corn value chain in Kutai Kartanegara Regency, East Kalimantan Province is explained as follows:

- Financial aspects. Source of funding for corn farming for farmers in Kutai Kartanegara Regency is the most basic. Farmers' access to funding sources is still very limited. This capital (financial) factor will directly affect farming, such as supplying production input at the right time is difficult to fulfil. Although basically corn farmers in Kutai Kartanegara Regency in supplying production input have been assisted by the government, for independent farmers this financial factor is crucial. Financial support, in this case, the supply of inputs, such as seeds and fertilizers, has the support of the central and regional governments. Including earth moving equipment (tractors) and corn thresher machinery, some farmers get help from the government;

- Information Aspects. Information currently available to farmers and traders is information about selling prices. Farmers and traders have not obtained good information on corn prices. Corn price information for farmers and traders is expected to be sourced from the government, especially the Regional Government of Kutai Kartanegara. The price information obtained is expected to be transparent for farmers and traders so that it will create healthy competition. Information about prices, both for farmers and traders, is not well obtained, so the price of corn received is not stable. The price of corn received by farmers and traders is by the mechanism of competitive sand, however, it does not rule out certain elements playing with prices during the main harvest;

- Business Partnership. The partnership is mutually beneficial cooperation, mutually reinforcing, mutual trust between partners who partner. Business partnerships are very important for developing and sustaining corn commodity in Kutai Kartanegara Regency. As the results of observations in the field of business partnerships in the commodity of corn in Kutai Kartanegara Regency have not been implemented. Business partnership cooperation has not been optimally implemented, resulting in farmers not being able to take advantage of the existence of business development services. Local government efforts are needed to promote this partnership from the beginning so that synergistic partnerships will develop, rather than lead to dispersal partnerships;

- Research Institute. Research institutes as a place to develop science and technology have a very big role in the development of sustainable corn (sustainable corn revolution). Based on observations in the field by gait researchers from the corn research institute in Kutai Kartanegara Regency, it is not optimal. At present, there are several research institutions for the development of corn commodities in the District of Kutai Kartanegara, although not yet specific to the commodity of corn. The research institutions are the Research Institute of the Kutai Kartanegara University, the Regional Research and Development Agency of the Kutai Kartanegara District, the Mulawarman University Research Institute in Samarinda, and the Samarinda Agricultural Technology Study Center.

Supply chain analysis. The supply chain is a network of several companies or organizations that work together to create and distribute a product to the hands of consumers or end-users. The supply chain not only consists of suppliers (suppliers) from factories but also distributors, transportation, warehousing, shops and consumers themselves. In the 
supply chain, three flows must be managed, namely: the flow of goods from suppliers to consumers, the flow of money from consumers to suppliers and the flow of information that moves both directions along the chain (Pujawan, 2005). Every function or process in the supply chain is supported by marketing, operational, distribution, financial and service processes for customers.

According to the results of research in the field shows that market participants in the chain of maize trading consist of farmers, village / sub-district level collectors, district-level collectors, retailers, feed industry and breeders as final consumers. The existing behaviour, market participants who are directly involved with producers are village / sub-district level traders, district-level collectors and breeders. The structure of the corn supply chain relationship is determined based on the members and their respective roles in forming the supply chain. Supply chain members are institutions or actors involved in product flow, financial flow, and information flow from corn growers to end consumers. The supply chain relationship structure consists of five members of the supply chain, namely corn farmers, village-level collectors (), sub-district level traders and consumers, which are divided into two, namely animal feed factories and breeders. Industries that are consumers in Kutai Kartanegara Regency include PT. Cheil Jedang Feed Kalimantan and CV Ayam Makmur Samarinda.

Corn supply chain channels in Kutai Kartanegara Regency are separated into several channels, namely:

1. Channel 0 level: Farmers - Consumers. This channel 0 level only consists of farmers as producers who sell their corn production directly to consumers of farmers with prices ranging from Rp. 3,500 to IDR. 6,000, with an average price of 240 respondents of IDR. 4,267 per kg.

2. Channel 1 A: Farmers - Village / sub-district / district collectors - industrial consumers.

Channel 1 B: Farmers - Retailers - Farmers' Consumers. In Channel 1A there are 2 channels where the actors (institutions) involved consist of farmers, village collectors (subdistricts) (districts), retailers and consumers both livestock farmers and the animal feed industry. Based on the results of research in the field $1 \mathrm{~A}$ channel is found in all districts except Marangkayu District which uses channel 1B. Channel $1 \mathrm{~B}$ is found in 4 districts namely Tenggarong District, Sebulu District, Muara Badak District and Marangkayu District while in Samboja District and Tenggarong District across using Channel $1 \mathrm{~A}$.

3. Channel 2: Farmers - Village (sub-district) (district collectors) - Retailers Consumers. Channel 2 for the corn supply chain in Kutai Kartanegara Regency was formed because collectors at the village (sub-district)(district) level were selling to retailers before being distributed to end consumers, namely farmers and animal feed industries. Channel 2 is based on the results of the study found in 3 districts namely Samboja District, Sebulu District and Muara Badak District.

4. Channel 3: Farmers - Village collectors (sub-districts) - Regency collectors Retailers - Consumers. Channel 3 is the longest channel in the Corn supply chain in Kutai Kartanegara Regency where channel 3 is located in two Subdistricts namely Tenggarong Seberang and Marangkayu. Channel 3 involves village (sub-district collectors), district collectors, retailers and consumers. According to Said et al (2006), the concept of agricultural trading used to assess the efficiency conditions in the corn supply chain includes the calculation of corn marketing margins as well as the farmer's share.

Marketing margin is the costs incurred and the benefits that each member of the supply chain receives in return for the contribution made. Each marketing institution has a different magnitude of marketing margins because each marketing agency carries out different marketing activities or functions.

The corn marketing margin in Kutai Kartanegara Regency is as in Table 2. The marketing margin also shows how much profit is gained by each channel involved in the supply chain of corn commodity in Kutai Kartanegara District. Based on Table 2, it can be seen that the largest supplier margin is obtained by the merchant collectors on channel 3. While the lowest is obtained by the regent trader on channel 3 . 
Table 2 - Margin and Advantages of Corn Supply Chain in Kutai Kartanegara Regency, East Kalimantan, 2020

\begin{tabular}{|c|c|c|c|c|c|c|}
\hline \multirow{2}{*}{\multicolumn{2}{|c|}{ Actors }} & \multicolumn{5}{|c|}{ Channel } \\
\hline & & & $1 \mathrm{~A}$ & 1B & 2 & 3 \\
\hline \multicolumn{7}{|c|}{ Farmers } \\
\hline - & Selling price (IDR per kg) & 4.989 & 4.469 & 4.000 & 4.100 & 4.000 \\
\hline \multicolumn{7}{|c|}{ Village/Sub-district level Collectors: } \\
\hline- & Purchase price (IDR) & & 4.469 & & 4.100 & 4.000 \\
\hline - & Selling price (IDR) & & 7.750939 & & 6.300 & 5.875 \\
\hline - & Costs (IDR per kg). & & 2.342 & & 865 & 334,5 \\
\hline - & profit $=$ selling price - purchase price- cost (IDR). & & & & 1.335 & $1.540,5$ \\
\hline - & Margin = selling price- purchase price (IDR) & & 3.281 & & & \\
\hline \multirow{2}{*}{\multicolumn{7}{|c|}{ District level collectors: }} \\
\hline & & & & & & \\
\hline - & Selling price (IDR) & & & & & $\begin{array}{l}6.000 \\
7.250\end{array}$ \\
\hline - & Costs (IDR per kg). & & & & & 195 \\
\hline - & Profit $=$ Selling price - purchase price - costs (IDR). & & & & & 1.055 \\
\hline - & Margin = selling price - purchase price (IDR) & & & & & \\
\hline \multirow{2}{*}{\multicolumn{7}{|c|}{ Retailers : }} \\
\hline- & Purchase price (IDR) & & & 4.000 & 6.300 & \\
\hline - & Selling price (IDR) & & & 7.750 & 8.800 & 9.000 \\
\hline - & Costs (IDR per kg). & & & 1.251 & 995 & 425 \\
\hline- & $\begin{array}{l}\text { Profit = Selling price }- \text { purchase price }- \text { costs (IDR). } \\
\text { Marain = selling price }- \text { purchase price (IDR) }\end{array}$ & & & 2.499 & 1.805 & 1.325 \\
\hline & & & & 3.750 & 1.800 & 1.750 \\
\hline \multicolumn{3}{|c|}{ Total selling costs (IDR). } & 939 & 1.251 & 1.860 & 954,5 \\
\hline \multicolumn{3}{|c|}{ Total profit (IDR). } & 2.342 & 2.499 & 3.140 & 3.920 \\
\hline & argin (IDR). & & 3.281 & 3.750 & 4.000 & 4.875 \\
\hline
\end{tabular}

Source: Primary data, processed by researchers.

The efficiency of marketing the corn commodity value chain. The marketing chain can be an indicator of the level of marketing efficiency that can be seen from the distribution of margins between the marketing chains. Marketing is said to be efficient if the price level received by farmers is getting better. However, other indicators can also be seen through the distribution of marketing margins.

The portion farmers receive from the price paid by the end consumer of the farmer's share is also analyzed to determine the efficiency of the corn supply chain. According to Said et.al. (2006), farmer share analysis is an analysis that uses the distribution of trading margins that can be seen based on the portion obtained by each supply chain actor with involvement in the output transformation process. Farmer's share has a negative relationship with the trading system margin, where the higher the value of corn trading system, the lower the farmer's share value. In this study, the Farmer's Share magnitude for each institution is as shown in Table 3.

Table 3 - Farmer's share supply chain of corn in Kutai Kartanegara Regency, 2020

\begin{tabular}{llll}
\hline \multirow{2}{*}{ Marketing channel } & Price level, farmers & Consumer-level price & Farmer's share \\
\cline { 2 - 4 } & (IDR per kg) & (IDR per kg) & $(\%)$ \\
\hline Channel 1A & 4.469 & 7.750 & 57,66 \\
Channel 1B & 4.000 & 7.750 & 51,61 \\
Channel 2 & 4.100 & 8.800 & 46,59 \\
Channel 3 & 4.000 & 9.000 & 44,44 \\
\hline
\end{tabular}

Source: Primary data, processed by researchers.

Farmer's share is an indicator of marketing efficiency in addition to marketing margins. This indicator measures how much corn farmers receive in return for their contribution to the final sale price of corn in a marketing channel. According to Downey and Erickson (1992) that marketing of agricultural products in terms of the price received by producer farmers is said to 
be efficient if the selling price of farmers is more than 40 per cent of the price of the consumer level. In this study, the farmer share value for all channels is above $40 \%$ with the highest value in channel 1 which is the shortest chain and the lowest value in channel 3 which is the longest chain of the corn supply chain in Kutai Kartanegara Regency.

Based on the actors involved, it can also be seen that marketing efficiency is based on the formula of Downey and Erickson (1992). The marketing system is said to be efficient if the value of marketing efficiency is $<1$. The results of the analysis as Table 4 shows that the efficiency value of all actors involved in corn marketing activities in Kutai Kartanegara Regency is efficient.

Table 4 - Corn marketing efficiency in Kutai Kartanegara District, 2020

\begin{tabular}{llll}
\hline Actors & Costs (IDR per kg) & Product Value (IDR per kg) & Efficiency Value (IDR per kg) \\
\hline Farmer & 2675,05 & 4312 & 0,63 \\
Village/Sub-district collector & 713 & 6642 & 0,11 \\
District collector & 195 & 7250 & 0,03 \\
Retailer & 890 & 8517 & 0,10 \\
\hline
\end{tabular}

Source: Primary data, processed by researchers.

\section{CONCLUSION}

Based on the analysis and the discussion that has been made, the conclusions of the study are as follows:

1. The function of corn farm production management, including; planning, organization, implementation, and supervision are running well, only the function of production supervision shows that corn production is still low. The total production of respondent farmers was $653,290 \mathrm{~kg}$ with an average of $1,855.94 \mathrm{~kg}$ per hectare. The selling price at the time of research activities was an average of IDR 4267 per kilogram. then the total farm income per planting season is IDR 4,938,016,750 with an average of IDR $2,748,685,000$ per hectare and an average of IDR $11,452,854$ per farmer. It is assumed for one planting season for three months so that the average income is IDR $6,858,357$ per month per farmer. The income was IDR 3,190,433,803 per planting season or IDR 4,431,158 per ha per planting season and IDR 9, 063,732 per farmer per planting season or IDR 3,021,244 per farmer per month. Based on the analysis of the $R$ / $C$ ratio value of 2.82, this shows that every IDR 1 cost incurred will obtain an income value of IDR. 2.82 and income value of IDR. 1.82, this shows that corn farming in Kutai Kartanegara District has provided profits to farmers so it is feasible to continue to be pursued;

2. Corn value chain in Kutai Kartanegara Regency, East Kalimantan Province involves three main actors, namely farmers, collectors, and traders. The corn value chain map shows several value chain actors in the various maize commodities, the longest flow, ie the actors involved consist of farmers - village collectors - retailers - consumers, and farmers - village collectors (sub-districts) - district collectors - animal feed industry, The next actors are farmers - district collectors - animal feed industry, farmers - retailers - consumers. While the short value chain, namely maize commodity from production activities carried out directly by corn farmers, consisting of farmers - consumers;

3. Margin received by farmers in channel IA is IDR 3,281, channel 2 is IDR 2,200 and channel is IDR 1,875 . The margin received by district collectors on channel 3 is IDR. 1,250 . The margin received by the retailer on the $1 \mathrm{~B}$ channel is IDR 3,750 on channel 2 , it is IDR 1,800, and on channel 3 it is IDR 1,750;

4. The efficiency value of all marketing institutions involved in corn marketing activities in Kutai Kartanegara Regency is $<1$ which means efficient. 


\section{ACKNOWLEDGEMENTS}

The researchers would like to thank all those who have helped in the process of completing this research, including the rector of the University of Kutai Kartanegara, the Dean of Agriculture Faculty and the Head of the Institute of Research and Community Service at the University of Kutai Kartanegara, Tenggarong for their permission and support for this research. Furthermore, gratitude to the Government of Kutai Kartanegara Regency through the Department of Industry and Trade for their cooperation and funding as stated in the cooperation letter number: B-542 / DISPERINDAG-BID-II / 065/8/2019, Number: 03 / AG / UKT-LPPM / VIII / 2019.

\section{REFERENCES}

1. Carlos, Moreno-Miranda, Pilamala Araceli, Cerda-Liliana Mejía, Víctor Mejía Rodrigo Cerda, Ortiz Jacqueline1, and Rama Daniele. (2018). A Socioeconomic and Productive. Characterization of the Value Chain of Goldenberry (Physalis peruviana) in Ecuador. Agricultural Sciences, 2018 (9): 426-436.

2. Downey and Erickson. 1992. Agribusiness Management. Jakarta: Erlangga. (in Indonesian).

3. Haryono. (2012). Maize for Food, Feed and Fuel in Indonesia: Challenges and Opportunity. Paper presented in the International Maize Conference. Gorontalo.

4. Irianto, Heru and Emy Widiyanti. (2013). Value Chain Analysis And Ear Fungus Agribusiness Marketing Efficiency In Karanganyar. SEPA, 9 (2): 260-272. (Abstract in English).

5. Khoi, Nguyen Viet. (2013). Wicked problems: a value chain approach from Vietnam's dairy products. Springer Plus, 2 (161): 2-6.

6. Kotler, Philip and Kevin Lane Keller. (2009). Marketing Management. Thirteenth edition. Volume 1. Jakarta: Erlangga publisher. (in Indonesian).

7. Lizano, Víctor Rodríguez and Mercedes Montero Vega. (2016). Costa Rican Meat Value Chain Description: Price Transmission as A Tool, International Journal of Food and Agricultural Economics, 4 (3): 91-101.

8. Magar, Dinesh Babu Thapa and Devendra Gauchan. (2016). Production, Marketing and Value Chain Mapping of 'Srijana' Tomato Hybrid Seed in Nepal. Journal of Nepal Agricultural Research Council, 2016 (2): 1-8.

9. Mubyarto. 1989. Introduction of Agricultural Economics. Jakarta: LP3ES. (in Indonesian)

10. Nassirou Ba, Mahamadou, (2017). Competitiveness of Maize Value Chains for Smallholders in West Africa: Case of Benin, Ghana and Cote D'lvoire. Agricultural Sciences, 2017 (8): 1372-1401.

11. Nassirou Ba, Mahamadou. (2016). Strategic Agricultural Commodity Value Chains in Africa for Increased Food: The Regional Approach for Food Security. Agricultural Sciences, 2016 (7): 549-585.

12. Nur, Yudha Hadian and Zamroni Salim. (2014). Local Virginia Tobacco Competitiveness: Value Chain Analysis. Journal of Economics and Development, 22 (1): 1-10. (Abstract in English).

13. Pujawan, IN. 2005. Supply Chain Management. Surabaya: Guna Wijaya. (in Indonesian)

14. Reji, Edakkandi Meethal. (2013). Value Chains and Small Enterprise Development: Theory and Praxis. American Journal of Industrial and Business Management, 2013 (3): 28-35.

15. Sagagi, Murtala S. and John Octavious S. Palina. (2013). Agricultural Value Chain Development How Can Empower Women in Developing Countries: Evidence from Nigeria And The Philippines, the International Journal of Arts \& Sciences, 6 (2): 757-763.

16. Said AI, Bayu US, Clara LB, Hoetomo L, Riri Satria, Soerjo W, and Zaldi IM. 2006. Productivity and Efficiency to Supply Chain Management. Jakarta: College of PPM. (in Indonesian). 
17. Soekartawi. 1989. Basic Principles of Agricultural Economics: Theory and Applications. Jakarta: Erlangga. (in Indonesian).

18. Supari Dh. 2001. Production and Operations Management Agribusiness Horticulture. First Edition. Jakarta: PT Elex Media Komputindo. (in Indonesian).

19. Suratiyah, Ken. 2006. Farming Sciences. Governmental spreader. Jakarta. (in Indonesian).

20. Tangenjaya B, Yusmichad Y, and Inspiration. (2002). Economic Analysis Demand Corn for Feed. National Discussion Corn Agribusiness Department of Agriculture Bogor. (in Indonesian).

21. Tanjung, Muhammad Hasan, Arief Daryanto, and Muladno. (2013). On the Competitive Strategy Value Chain Broiler PT Ciomas Adisatwa Region Unit Bogor, West Java. Journal of Management and Agribusiness, 10 (1), 40-49. (Abstract in English).

22. Tobin, Daniel, Mark Brennan, and Rama Radhakrishna. (2016). Food access and propoor value chains: a community case study in the central highlands of Peru. Agric Hum Values, 2016 (33): 895-909.

23. Widiastuti, and Mohd Nur. Harisudin. 2013. Channels and Marketing Margin Corn in Grobogan. SEPA, 9 (2), 231-240. (Abstract in English). 